\title{
CHANGES IN PROTEIN CONTENT OF ARGAS (PERSICARGAS) PERSICUS (ACARI: ARGASIDAE) OVARY AFTER TREATMENT WITH ALLIUM SATIVUM EXTRACT
}

By

OLA H. ZYAAN, SHIMAA S. AHMED and MOHAMED A. ABDOU*

Department of Entomology, Faculty of Science, Ain Shams University, Cairo 11566, Egypt ( ${ }^{\star}$ Correspondence: drmabdou@sci.asu.edu.eg;ORCID:00000002-2285-7246)

\section{Abstract}

Argas (Persicargas) persicus is a parasitic feeder on blood of poultry birds. After each blood meal a female is capable of producing a large numbers of eggs, the hatched larva remains attached to its bird host for seven or more days and draw numerous bulky blood meals. The ovary is the main factory part for the oogenesis (production of eggs). The targeting treatment with ecofriendly acaricide is required to disrupt the normal physiology of the ovary. This study aimed to analyse and quantify total and fractionated protein in the ovary of $A$. persicus females treated with Allium sativum extracts from fresh garlic bulbs. Group of engorged females were topically treated with garlic extract at $1.44 \%$ concentration, and another group with water (control). All females were crossed independently with normal males. In order to analyze the proteins of the ovary, untreated females were dissected $0,1,2,3,4,5,6,7, \& 20$ days after feeding (DAF), represented different physiological states of tick and the treated females were dissected 3, 4, 5, 6, 7, $\& 20$ DAF. The ovaries were homogenated and subjected to standard total and fractionated protein techniques. The protein concentration in ovary was significantly higher $(P<0.05)$ in controls than in treated ones. Fractionated protein showed five characteristic bands to vitellogenesis process in controls. They reached highest concentration level at $7^{\text {th }}$ days after feeding (DAF). These five bands disappeared in the treated samples except for one band in the corresponding time.

Keywords: Argas (Persicargas) persicus; Allium sativum (garlic bulbs extracts); Vitellogenesis; Total protein; SDS-PAGE protein.

\section{Introduction}

Agriculturists in developing countries are suffering from many diseases that reduce the productivity of their livestock, many of these diseases related to tick infestations. There are 800 species of ticks around the world are known and most of them can carry disease causing agents giving rise to health problem (Thorsell et al, 2006).

Argas persicus is a common poultry tick across the world from Africa (Sabuni, 2010), Asia (Aghighi et al, 2007; Al-Saffar et al, 2008), Europe and America (Acuna et al, 2005). A bite of $A$. persicus may cause muscle paralysis (Adelusi, 1999). It causes serious irritation to poultry which has an adverse effect on their production and cause heavy economic damages in poultry industry (Phulan et al, 1984; Shah et al, 2004). Heavy infestations of Argas persicus cause loss of blood leading to anemia and sooner or later death (Bergstrom et al, 1999).
The main common method for controlling ticks is depending on the use of synthetic acaricides. However, continuous use of these compounds can lead to accumulation of toxic residues in food, contamination of environment, poisoning of animals and humans, and increase the chance of arising of resistant ticks (Sonenshine, 1991). The appearance of tick resistance to acaricides has been a major determinant of the need for new control methods (George, 2000).

The challenge is looking for other possible tick control method as plant extract to minimize the adverse effects of prolonged and intensive use of chemical acaricides (Olivo et al, 2009). Mordue and Nisbet (2000) stated that the plant has an effect on the neuroendocrine system of insects. Several compounds extracted from plants have prospective insecticidal, growth limiting or repellent features (Isman, 2006; Pavela, 2008).

Essential oils of plants that can be extract- 
ed from plant tissue by water steam distillation or supercritical fluid extraction are commonly used in the prevention and treatment of human illnesses. Various essential oils (garlic oil, onion oil...etc.) have also been recorded to exhibit severe toxic effects against ticks (Aboelhadid et al, 2013). Such intoxication were found correlated with some biochemical changes in the tested species as a decrease or increase of total and certain protein fraction pattern, that lead to certain functional and physiological interactions (Mohamed and Hafez, 2000).

Allium sativum (Garlic) is one of the important components of human food and ingredients medicines since ancient time. It is used as antioxidant, diuretic, heart stimulating, gastrointestinal, and anti-hypertension agent. Bulbs of garlic contain several active compounds particularly Sulphur containing compounds accountable for pharmacological properties. Steam distillation of garlic bulb produces essential oil containing mainly of diallyl, allyl methyl and dimethyl mono to hexa sulfide (Lawson, 1993). They have acaricidal (El-Zemity et al, 2006), antibacterial (Ross et al, 2001), fungicidal (Ledezma and Apitz-Castro, 2006) and insecticidal (Hasan, 2012) properties. Acheuk et al. (2012) observed no protein band corresponding to vitellogenin (vitellin) polypeptides in Locusta migratoria on day 12 after emerge posttreatment with methanolic extract of Haplophyllum tuberculatum. Aqueous Neem extract has an inhibitory effect on vitellogenesis of Rhipicephales sanguineus (Denardi et al, 2010). Shyma et al, (2014) reported that treatment of Boophilus microplus with garlic extract inhibited significantly the fecundity and produced complete failure of eclosion of eggs from ticks at lower concentrations.

This work aimed to study the effect of sublethal dosage of Allium sativum extract on quantitative and qualitative protein contents of Argas persicus females' ovary.

\section{Materials and Methods}

Ticks rearing: The soft ticks, Argas (Persicargas) persicus (Oken) samples were collected from a domestic chicken house at Banysweef Governorate, Egypt. To start a laboratory colony, ticks were kept at $27^{\circ} \mathrm{C} \pm 1,75 \% \mathrm{RH}$ and $16 \mathrm{hrs}$ day light. The ticks were detained in transparent polyethylene tubes $(25 \times 100$ or $13 \times 100 \mathrm{~mm})$, which were sealed at one end by a plaster of pairs plug (rearing tube) and enclosed at the other end with muslin cloth securely held by rubber bands (Kaiser, 1966). Domestic pigeons, (Columba livia) from commercial breeder in Cairo, were used as a blood source for ticks feeding. The colony and the host were kept in an insectary provided by the Department of Entomology, Ain Shams University. The pigeon host was tied to a wooden panel with one wing overextended laterally. The inner wing feathers were pulled and ticks (adults and nymphs) were placed to feed on the wing for about 15-20 min. Following engorgement, ticks were transferred to a Petridis comprising a filter paper disk and observed until coxal fluid was released.

Allium sativum extract: Garlic (Allium sativum) extract was prepared by exposing the fresh plant bulbs to steam distillation to obtain the extract. The attained extract was purified chromatographically by HPLC (Rembold et al, 1984).

The preparation of ticks for biochemical analysis: A single dose $(10 \mu 1 /$ female $)$ of $1.44 \%$ garlic extract was topically applied on posterior half of the adult fed female ventral side on the $3^{\text {rd }}$ day after feeding. A treated female and normal male were kept independently at $27^{\circ} \mathrm{C}, 75 \% \mathrm{RH}$ in an insectary. To analyze proteins of the ovary, the untreated females were dissected $0,1,2,3,4$, $5,6,7, \& 20$ days after feeding (DAF) which represented different physiological states of tick and the treated females were dissected 3, 4, 5, 6, 7, \& 20 DAF. Three ovaries of normal or treated A. persicus females from each fed groups were homogenized for biochemical analysis in Eppendorf tube with $1 \mathrm{X}$ phosphate buffered saline (PBS) buffer $(137 \mathrm{mM} \mathrm{NaCl}, 10 \mathrm{mM}$ Phosphate, $2.7 \mathrm{mM} \mathrm{KCl}$, and a $\mathrm{pH}$ of 7.4). After 
homogenation, centrifuged at 4000 r.p.m. for $10 \mathrm{~min}$. at $4^{\circ} \mathrm{C}$, supernatants were kept in a freezer at $-20^{\circ} \mathrm{C}$ till use for biochemical assays.

Quantification of total protein contents: Total proteins were quantified by the method of Bradford (I976). To prepare the protein reagent, $100 \mathrm{mg}$ of Coomassie Brilliant blue G-250 was dissolved in 50ml 95\% ethanol. To the previous solution, a $100 \mathrm{ml}$ of $85 \%(\mathrm{~W} / \mathrm{V})$ phosphoric acid was added. The resulting solution was completed to a final volume of one liter. Ten microliter of each protein sample was mixed with $500 \mu$ l of the protein reagent, kept for five minutes at room temperature, and the absorbance at 595 $\mathrm{nm}$ was measured against blank prepared from $10 \mu 1$ of phosphate buffer and $500 \mu \mathrm{l}$ protein reagent. The corresponding protein concentrations were calculated depending on the protein standard curve which made by serial concentrations of bovine serum albu$\min (0.2-1.4 \mathrm{mg} / \mathrm{ml})$

Protein electrophoretic analysis: Protein fractionated by SDS polyacrylamide gel electrophoresis (PAGE) as designated by Smith (1976); using slab gel that consist of a $4 \%$ polyacrylamide stacking gel and an acrylamide $(12 \%)$ gel. Wide range of protein marker was used for the determination of protein profiles of all fractionated samples. Electrophoresis was done at room temperature using $80 \mathrm{~mA}$ for approximately four hours. The gel was then stained with Coomassie Brilliant blue for protein. Gels were scanned and analyzed by Core Laboratory Image Quantification Software (CLIQS). This program is a comprehensive computer software application designed to determine the number, molecular weight, the percentage amounts, and relative fragmentation values of fractionated bands of each lane.

Statistical analysis: Data were subjected to analysis of variance (ANOVA) and followed by Tukey's HSD tests with the help of SPSS version19, in which the equation of the standard errors, standard deviation, Tstatistic values and probabilities $(P)$ were used. The level of significance: was expressed as significant when $P<0.05$.

\section{Results}

The total protein concentration in the ovary of normal mated fed female A. persicus was without significant $(\mathrm{P}>0.05)$ change up to the $5^{\text {th }}$ day after feeding (DAF). Protein concentrations were $0.570 \pm 0.028,0.630 \pm 0.011$, $0.677 \pm 0.016,0.706 \pm 0.010,0.748 \pm 0.012, \&$ $0.759 \pm 0.008 \mathrm{mg} /$ ovary on the $0,1,2,3,4, \&$ $5 \mathrm{DAF}$, respectively. A significant increase in protein level $(\mathrm{P}<0.05)$ was seen on $6^{\text {th }} \&$ $7^{\text {th }}$ DAF to reach $0.985 \pm 0.007 \& 1.060 \pm$ $0.021 \mathrm{mg} /$ ovary, respectively. Total protein then was reduced significantly $(\mathrm{P}<0.05)$ to $0.654 \pm 0.018 \mathrm{mg} /$ ovary in the $20^{\text {th }} \mathrm{DAF}$.

On the other hand, data showed that the total protein concentration in the ovary of mated fed female $A$. persicus treated topically with $1.44 \%$ garlic extract on the $3^{\text {rd }}$ day after feeding (DAF) showed no significant $(\mathrm{P}>$ $0.05)$ changed up to $20^{\text {th }}$ DAF. Protein concentrations were $0.495 \pm 0.011,0.666 \pm 0.011$, $0.715 \pm 0.003,0.748 \pm 0.008,0.758 \pm 0.006, \&$ $0.635 \pm 0.002 \mathrm{mg} /$ ovary on the $3,4,5,6,7$, and $20 \mathrm{DAF}$, respectively.

In comparison between total protein of normal and garlic treated mated females $A$. persicus ovaries, there was a significant great reduction $(\mathrm{P}<0.05)$ in the level of total protein on the $7^{\text {th }}$ DAF of treated females. At this time the percent reduction was $28.5 \%$ relative to its corresponding state in normal female. Also, there were reductions in the levels of total protein on the $3^{\text {rd }}, 4^{\text {th }}$, $5^{\text {th }}, 6^{\text {th }}$, and $20^{\text {th }}$ DAF of treated females by values of $29.87 \%, 15.05 \%, 5.8 \%, 24.06 \%$, and $2.91 \%$, respectively relative to corresponding values in normal female.

Fractionated protein from ovary of normal female $A$. persicus and treated with garlic extract: Proteins were analyzed by SDSPAGE technique. Normal females were dissected on days $0,1,2,3,4,5,6,7, \& 20$ DAF and the proteins were extracted from the obtained ovaries corresponding to each day.

Data (Tab, 1; Fig. 2) showed that ovary's 
protein from samples of $0,1,2,3,4,5,6,7$, \& 20 DAF were separated into 9, 10, 16, 20, $17,21,19,22$, \& 9 bands, respectively. Molecular weight of bands in all normal samples ranged from 19 to $331 \mathrm{KDa}$ for 34 different bands. Bands number 25, 28, 30, \& 34 were found to be common between all normal samples with molecular weight 30, 26, 22, \& 19 KDa. Bands number 1 and 24 were characteristic to sample 7 DAF with molecular weight $331 \& 31.5 \mathrm{KDa}$, respectively. Band number 14 was characteristic to sample 4 DAF with molecular weight 79.7 KDa. In sample 5 DAF, only $10^{\text {th }}$ band with molecular weight $102 \mathrm{KDa}$ was characteristic band to this sample. Also, bands number 19, $11,21,20,25,28,21,30, \& 19$ were found to have the highest density with percentage amount 45.3, 32.5, 19.9, 23.7, 22.2, 15.6, $17.5,13.2, \& 36.8$ in samples $0,1,2,3,4,5$, $6,7, \& 20$ DAF, respectively. Data showed that bands numbers $6,8,9,13, \& 15$ were common in samples of $5,6, \& 7 \mathrm{DAF}$ and were with molecular weight of $218,145.5$, $113,84.6, \& 74.9 \mathrm{KDa}$, respectively.

These five bands $(6,8,9,13, \& 15)$ appeared about two, three, four, three, and two times, respectively, as percentage amount in the sample 7 DAF than in samples $5 \& 6$ DAF and also these five bands were disappear completely from sample 20 DAF except for the band number 15 which was reduced by $75 \%$ to $1 \%$ amount value in that sample.

Table 1: Relative mobility $(\mathrm{Rm})$ and concentration of different fractionated protein bands detected in whole homogenates from ovary of female A. persicus after different days of feeding.

\begin{tabular}{|c|c|c|c|c|c|c|c|c|c|c|c|}
\hline \multirow{2}{*}{$\begin{array}{c}\text { Band } \\
\text { No. }\end{array}$} & \multirow{2}{*}{$\mathrm{Rm}$} & \multirow{2}{*}{$\begin{array}{c}\text { Molecular } \\
\text { wt. KDa }\end{array}$} & \multicolumn{9}{|c|}{ Band $\%$} \\
\hline & & & $0 \mathrm{DAF}$ & $1 \mathrm{DAF}$ & $2 \mathrm{DAF}$ & $3 \mathrm{DAF}$ & $4 \mathrm{DAF}$ & $5 \mathrm{DAF}$ & $6 \mathrm{DAF}$ & $7 \mathrm{DAF}$ & $20 \mathrm{DAF}$ \\
\hline 1 & 0.02 & 331 & - & - & - & - & - & - & - & 0.4 & - \\
\hline 2 & 0.03 & 321.2 & - & - & - & - & - & 1.9 & 3.2 & - & - \\
\hline 3 & 0.04 & 306.4 & - & - & 2.8 & 2.1 & 3 & - & - & - & - \\
\hline 4 & 0.05 & 287.8 & - & - & - & - & - & - & 2.4 & 0.6 & - \\
\hline 5 & 0.08 & 246 & - & - & 4.3 & 3.9 & 4.3 & 7.4 & - & - & - \\
\hline 6 & 0.11 & 218 & - & - & - & - & - & 1.9 & 2 & 4.1 & - \\
\hline 7 & 0.17 & 160.6 & - & - & 7.3 & 0.1 & - & - & - & - & - \\
\hline 8 & 0.19 & 145.5 & - & - & - & - & - & 3 & 3.1 & 9.1 & - \\
\hline 9 & 0.24 & 113 & - & - & - & - & - & 2.5 & 2.4 & 10.1 & - \\
\hline 10 & 0.27 & 102 & - & - & - & - & - & 11.1 & - & - & - \\
\hline 11 & 0.29 & 93.3 & - & 32.5 & - & 13.5 & - & - & 3.9 & - & - \\
\hline 12 & 0.3 & 89.9 & - & - & 0.1 & 2.1 & 12.7 & - & - & - & - \\
\hline 13 & 0.31 & 84.6 & 1.7 & 4 & 4.6 & 1.8 & 3.2 & 2.6 & 2.5 & 7.8 & - \\
\hline 14 & 0.33 & 79.7 & - & - & - & - & 0.2 & - & - & - & - \\
\hline 15 & 0.34 & 74.9 & - & - & 9.1 & 1.4 & 1.6 & 2 & 1.9 & 3.9 & 1 \\
\hline 16 & 0.39 & 62.9 & 12 & 17.7 & - & 7.5 & 5.6 & 6.5 & - & 2.2 & 8.1 \\
\hline 17 & 0.41 & 56.5 & - & - & - & 5.4 & 9.6 & 7.3 & 6.7 & - & - \\
\hline 18 & 0.43 & 52.7 & - & - & 7.7 & - & - & - & 5.8 & 5.6 & - \\
\hline 19 & 0.46 & 47.6 & 45.3 & 0.9 & 0.6 & 0.3 & - & - & - & 2.6 & 36.8 \\
\hline 20 & 0.48 & 45.5 & - & - & - & 23.7 & 1.1 & 4.3 & 3.7 & 2 & - \\
\hline 21 & 0.51 & 40.6 & 26.9 & 0.3 & 19.9 & - & - & - & 17.5 & 4.6 & - \\
\hline 22 & 0.53 & 38.2 & - & - & - & - & - & 11.6 & - & 2.3 & - \\
\hline 23 & 0.57 & 34.9 & - & - & - & - & - & - & - & 7.1 & 17.8 \\
\hline 24 & 0.61 & 31.5 & - & - & - & - & - & - & - & 0.5 & - \\
\hline $25^{*}$ & 0.63 & 30 & 0.7 & 18.1 & 2.2 & 1.8 & 22.2 & 2.8 & 2.5 & 2.4 & 1.8 \\
\hline 26 & 0.65 & 28.5 & 10 & 2.3 & 1.9 & - & 2.1 & 1.8 & 5.7 & 7 & 5.4 \\
\hline 27 & 0.67 & 27.7 & - & - & 5.8 & 3.9 & - & 2.9 & 4.3 & - & - \\
\hline $28^{*}$ & 0.7 & 26 & 0.2 & 21.7 & 3.6 & 3.6 & 15.8 & 15.6 & 15.3 & 0.4 & 20.4 \\
\hline 29 & 0.72 & 25 & - & - & 12.9 & 0.6 & - & - & - & - & - \\
\hline $30 *$ & 0.83 & 22 & 3.1 & 0.4 & 0.9 & 15.2 & 1.7 & 3.3 & 5.5 & 13.2 & 8.4 \\
\hline 31 & 0.86 & 21 & - & - & - & 3.6 & 8.3 & 3.5 & 7.9 & 6.9 & - \\
\hline 32 & 0.9 & 20.7 & - & - & - & 5 & 3.3 & 3.2 & - & 6 & - \\
\hline 33 & 0.95 & 20 & - & - & - & 4.3 & 3 & 1 & - & - & - \\
\hline $34 *$ & 0.97 & 19 & 1 & 2.2 & 16.2 & 0.2 & 2.3 & 3.7 & 3.8 & 0.9 & 0.2 \\
\hline \multicolumn{3}{|c|}{ Total number of bands } & 9 & 10 & 16 & 20 & 17 & 21 & 19 & 22 & 9 \\
\hline
\end{tabular}


The treated females with the garlic extract were dissected on days $3,4,5,6,7, \& 20$ $\mathrm{DAF}$ and the proteins were extracted from the obtained ovaries corresponding to each day. Densitometric scanning of electropherogram of SDS protein (Tab. 2, Fig. 3) revealed that, ovary protein from samples of 3 , 4, 5, 6, 7, and $20 \mathrm{DAF}$ were separated into 8, $10,12,11,14$, and 9 bands, respectively. The molecular weight of bands in all treated samples ranged from 22 to $161 \mathrm{~K} \mathrm{Da}$ for 17 different bands. Bands number 1, 4, 6, 9, 10, 14 and 16 were found to be common between all treated samples with molecular weight 161, 90, 77, 44, 40, 26 and $23 \mathrm{KDa}$. Bands number $13 \& 15$ were characteristic to sample 5 DAF with molecular weight $27.7 \& 24.5 \mathrm{KDa}$, respectively. While, band number 11 was characteristic to sample 7 DAF with molecular weight $35 \mathrm{KDa}$. In addition, bands number $16,17,1,7,17, \& 10$ showed the highest density with percentage amount 26.6, 21.1, 19.9, 16.8, 19.2, \& 23.9 in samples $3,4,5,6,7$, \& $20 \mathrm{DAF}$, respectively.

On the other hand, five bands were detected in control samples with molecular weight of $331,321.2,306.4,287.8$, and $246 \mathrm{KDa}$ were disappeared in the treated samples with tested compound which indicates the failure in expression of high molecular weight proteins in the treated samples.

It's well known that vitellogenesis processes in ticks require several proteins which start to increase (or appear) gradually from the fifth day after blood feeding and reach the highest level at the seventh day after blood feeding to reach the fully mature oocytes in the ovary.

When comparing the treated sample of 7 DAF it was noticed that number of bands was decreased to 14 bands compared to 22 bands in the corresponding control sample. Comparing the control protein patterns with the patterns of treated sample of 7 DAF with garlic extract revealed the disappearance of three protein band which are characteristic to vitellogenesis processes. Where in the control sample of $7 \mathrm{DAF}$, there were five protein bands representing the vitellogenesis processes with molecular weight $218,145.5$, 113, 84.6, and 74.9 K Da. While in treated sample of 7 DAF, only one protein band was detected from the five previously mentioned bands with molecular weight $113 \mathrm{KDa}$ and $80 \%$ reduction in percentage amount compared to the control sample at the same day.

Table 2: Relative mobility and concentration of different fractionated protein bands detected in homogenates from ovary of treated Argas persicus females with garlic extract after different days of feeding.

\begin{tabular}{|c|c|c|c|c|c|c|c|c|}
\hline \multirow{2}{*}{$\begin{array}{l}\text { Band } \\
\text { No. }\end{array}$} & \multirow{2}{*}{$\mathrm{RF}$} & \multirow{2}{*}{$\begin{array}{l}\text { Molecular } \\
\text { weight KDa }\end{array}$} & \multicolumn{6}{|c|}{ Band $\%$} \\
\hline & & & $3 \mathrm{DAF}$ & $4 \mathrm{DAF}$ & $5 \mathrm{DAF}$ & $6 \mathrm{DAF}$ & $7 \mathrm{DAF}$ & $20 \mathrm{DAF}$ \\
\hline $1 *$ & 0.17 & 161 & 4.7 & 11.2 & 19.9 & 5.2 & 7.5 & 6.9 \\
\hline 2 & 0.23 & 127 & - & - & - & 7.9 & 6.8 & - \\
\hline 3 & 0.27 & 113 & - & - & - & 2.1 & 2 & - \\
\hline $4 *$ & 0.3 & 90 & 6 & 3.6 & 6.1 & 6.4 & 5 & 4.5 \\
\hline 5 & 0.34 & 84.6 & 2.2 & 5.1 & 3.3 & - & - & 4.3 \\
\hline 6* & 0.36 & 77 & 22.9 & 13.4 & 11 & 6.5 & 5.3 & 17.6 \\
\hline 7 & 0.39 & 70 & - & - & - & 16.8 & 9.4 & - \\
\hline 8 & 0.45 & 54 & - & 11.8 & 5.8 & - & 3.1 & - \\
\hline $9 *$ & 0.53 & 44 & 5.4 & 6.6 & 4.3 & 4.1 & 5.2 & 4.7 \\
\hline $10^{*}$ & 0.55 & 40 & 19.9 & 5 & 7.9 & 12.9 & 8.8 & 23.9 \\
\hline 11 & 0.62 & 35 & - & - & - & - & 3.7 & - \\
\hline 12 & 0.67 & 31 & - & - & - & 7.8 & 7.8 & - \\
\hline 13 & 0.74 & 27.7 & - & - & 6.3 & - & - & - \\
\hline $14^{*}$ & 0.77 & 26 & 12.3 & 6.4 & 5.1 & 3.4 & 3.4 & 6.7 \\
\hline 15 & 0.81 & 24.5 & - & - & 5.1 & - & - & - \\
\hline $16^{*}$ & 0.86 & 23 & 26.6 & 15.6 & 8.5 & 9.8 & 12.9 & 12 \\
\hline 17 & 0.9 & 22 & - & 21.1 & 16.8 & - & 19.2 & 19.5 \\
\hline \multicolumn{3}{|c|}{ Total number of bands } & 8 & 10 & 12 & 11 & 14 & 9 \\
\hline
\end{tabular}




\section{Discussion}

Proteins are synthesized in the fat body and later released into the haemolymph to be incorporated later into several organs including the ovaries (Vallae, 1993). In ticks, synthesis of vitellogenin occurs outside of the ovaries then released into the hemolymph for later uptake by ovary (Diehl and Dotson, 1986). The period of the increase of the ovary protein level coincided with the progress of vitellogenesis (3-7 DAF) as showed by number of mature oocytes (Radwan et al, 2015). The increase in total protein in the ovaries of the mated fed female A. persicus during this period may indicate an uptake of heamolymph proteins by the ovaries or an increase in protein synthesis by the ovaries or both (Engelmam, 1979).

In the present work, total protein concentration in the ovaries of the mated females $A$. persicus gradually increased after feeding to reach the maximum level on $5-7^{\text {th }}$ day after blood feeding. Similar results were obtained in A. hermanni (Shanbaky et al, 1990b), Ixodes scapularis (James and Oliver, 1996), and A. persicus (Radwan et al, 2015).

An increase in the ovary protein level was reported by Shanbaky et al, (1990b) in the mated engorged A. hermanni. The period of the increase of the ovary protein level correlated with the progress of vitellogenesis (3-6 DAF) as determined by the weight of the ovaries and the number of mature oocytes. Furthermore the increase of the level of the ovarian total protein was associated with an increase of the level and the number of the exogenous vitellins during the period of vitellogenesis (3-6 DAF) suggesting an uptake of protein by ovary during vitellogenesis. Also the concentration of vitellin in Ixodes scapularis ovaries was declined after oviposition (James and Oliver, 1996).

Araman (1979) showed the ability of ovarian tissue to synthesis yolk proteins in female R. sanguineus and Jenni (1971) found an endogenous protein synthesis by oocyte and uptake of hemolymph vitellogenins into oocytes by micropinocytosis in the female
Ornithdorous moubata during the vitellogenesis.

After treatment with garlic extract the concentration of ovary total proteins was changed during the reproductive cycle of the female A. persicus. Application of garlic on the $3^{\text {rd }}$ DAF prevented any increase in the level of total proteins of the ovaries on the next days (4-7 DAF). This suggests an impairment of protein production in both tissues which could be attributed to an interference with blood meal digestion, protein synthesis, and release into the haemolymph and uptake in the ovary. It might have disturbed or hindered with the normal physiology of the treated tick causing an observed reduction of the protein levels in the ovaries. The reduction of the proteins in the ovary will lead to reduction or inhibition in the vitellogenesis as reported previously by Shyma $e t$ al, (2014) where the treatment of Boophilus microplus with garlic extract was able to inhibit significantly the fecundity and produced complete failure of eclosion of eggs from the treated ticks even at lower concentrations.

The treatment with $A$. sativum may lead to an effect of natural putative hormone in $A$. persicus as in other Argasids (Shanbaky et al, 1990a) might have disturbed or interfered with normal physiology of treated ticks leading to observed reduction in protein level in the ovaries.

Plant extract can inhibit the molting process by interfering with the neuroendocrine system and altering the levels of ecdysteroid hormone in the hemolymph (Schmidt et al, 1998).

In the present study, lower protein concentration was observed in the ovaries of engorged females treated with A. sativum extract than in the controls. The most abundant protein in tick eggs was Vitellogenin represented about $11 \%$ of total protein in hemolymph (Sonenshine, 1991). After female engorgement, concentration of Vitellogenin in hemolymph increased and regulated by uptake in oocytes (Seixas et al, 2010). Since 
the treated females had fewer vitellogenic oocytes, it was assumed that the accumulation of protein in hemolymph occurred as the vitellogenin was not taken up by oocytes (Sousa et al, 2013). Borges et al. (1994; 2003) and Sousa et al. (2008; 2011) reported high efficacy against tick reproduction from fruit extracts. The results agreed with Madhavi (2016) where Corcyra cephalonica larvae showed a decline in the protein content when compared to control ones after treatment with crude bulb extract of A. sativum. This may be due to the A. sativum is functioning as a molting hormone analogue.

Medina et al. (2004) explained the lack of yolk granules in the oocytes from treated female Chrysoperla carnea due to the effect of Azadirachitin on vitellogenin synthesis or its uptake by oocytes. Oogenesis and vitellogensis in this insect are controlled by Juvenile hormone (Rousset, 1988).

SDS-PAGE revealed differences in bands numbers and molecular weights in both control and treated ovary proteins of females. Garlic extract affected the proteins of ovary. It destructed the protein structure thus inducing the formation of new protein bands. Garlic extract induces more differences in the molecular weights of proteins of ovary.

Responsible proteins for vitellogenesis process were noticed in high concentration in $7^{\text {th }}$ DAF represented in five protein bands with molecular weight $218,145.5,113,84.6$, $\& 74.9 \mathrm{KDa}$. These five protein bands were disappeared in the corresponding treated sample except for one protein band with molecular weight $113 \mathrm{KDa} \& 80 \%$ reduction in amount. These data clarified the reduction in eggs hatchability and defect in oocyte formation in treated $A$. persicus females with $A$. sativum extract. The results agreed with $\mathrm{Lu}-$ cantoni et al. (2006) who treated Anopheles stephensi, with Neem found a delay in development oocytes in vitellogensis and chorionogenesis phases. Acheuk et al. (2012) reported methanolic extracts of leaves and stems of Haplopphyllum tuberculatum affected reproduction in Locusta migratoria females by disrupting vitellogenesis, ovarian development and ecdysteriod production. Inhibition of vitellogenesis and oocytes growth was due to suppression of ecdysteriod production in treated insects and terminal oocytes were maintained in a juvenile state or delayed in reaching maturation.

A. sativum essential oil reduced the oviposition potential in adults of Tribolium castaneum when treated with sublethal concentrations by both fumigation and contact methods (Chaubey et al, 2013). Essential oils on insects were studied and treatment with several oils and/or their constituents caused a neurotoxic mode of action (Kostyukovsky et al, 2002; Priestley et al, 2003). Allicin is a phytochemical present in garlic that interferes with RNA production and lipid synthesis. If RNA synthesis is affected or produced in fewer amounts then protein synthesis is severely affected (Meriga et al, 2012).

\section{Conclusion}

The outcome results showed that steam distillation extract of bulbs of $A$. sativum significantly reduced total protein in females' ovary and disrupted vitellogenesis. Protein reduction in the ovary would consequently cause reduction in oogenesis process.

The authors contributed equally to this work

\section{References}

Aboelhadid, SM, Kamel, AA, Arafa, WM, Shokier, KA, 2013: Effect of Allium sativum and Allium cepa oils on different stages of Boophilus annulatus. Parasitol. Res. 112:1883-90.

Acheuk, F, Cusson, M, Doumandji-Mitiche, B, 2012: Effects of a methanolic extract of the plant Haplophyllum tuberculatum and of teflubenzuron on female reproduction in the migratory locust, Locusta migratoria (Orthoptera: Oedipodinae). J. Insect Physiol. 58:335-41.

Acuna, DG, Guglielmone, AA, 2005: Ticks (Acari: Ixodoidea: Argasidae, Ixodidae) of Chile. Exp. Appl. Acarol. 35:147-63.

Adelusi, SM, Vajime, CG, Omudu, EA, Okpotu RO, Onazi, FO, 1999: Avian ectoparasitism in Makurdi, Nigeria: Do wild birds serve as reservoir for domestic birds? Vet. Parasitol. 84:33747.

Aghighi, Z, Assmar, M, Piazak, N, Javadian, E, Seyedi, RMA, et al, 2007: Distribution of so- 
$\mathrm{ft}$ ticks and their natural infection with Borrelia in a focus of relapsing fever in Iran. Iranian J. Arthropod Borne Dis. 1, 2:14-8.

Al-Saffar, TM, Al-Mawla, ED, 2008: Some hematological changes in chickens infected with ecto-parasites in Mosul. Iraqi J. Vet. Sci. 22, 2: 95-100.

Araman, SF, 1979: Protein Digestion and Synthesis in Ixodid Females. In: Advances in Acarology, I.J.G. Rodriguez (ed.), Recent. Academic, New York.

Bergstrom, S, Haemig, PD, Olsen, B, 1999: Increased mortality of black-browed albatross chicks at a colony heavily-infested with the tick $I x$ odes uriae. Int. J. Parasitol. 29:1359-61

Borges, LMF, Ferri, PH, Silva, WJ, Silva, W C, Silva, JG, 2003: In vitro efficacy of extracts of Melia azedarach against the tick Boophilus microplus. Med. Vet. Entomol. 17, 2:228-31.

Borges, LMF, Silva, AC, Neves, BP, 1994: Teste "in vitro" de eficácia de cinamomo (Melia azedarach, L.) sobre fêmeas ingurgitadas do Boophilus microplus, Can. (Acari: Ixodidae). Rev. Pat. Trop. 23, 2:175-9.

Bradford, MM, 1976: A rapid and sensitive methods of the quantitation of microgram quantities of protein utilizing the principle of protein dye binding. Anal. Biochem. 72:248-54

Chaubey, MK, 2013: Biological activities of $Z i$ ngiber officinale (Zingiberaceae) and Piper cubeba (Piperaceae) essential oils against pulse beetle, Callosobruchus chinensis (Coleoptera: Bruchidae). Pak. J. Biol. Sci. 16, 11:517-23.

Denardi, SE, Bechara, GH, Oliveira, BR, Camargo-Mathias, MI, 2010: Azadirachta indica A Juss (neem) induced morphological changes on oocytes of Rhipicephalus sanguineus (Latreille, 1806) (Acari: Ixodidae) tick females. Exp. Parasitol. 126:462-70

Diehl, PA, Dotson, EM, 1986: Chemistry, function, and metabolism of tick ecdysteroids. In: Morphology, Physiology and Behavioral Biology of Ticks. Sauer, JR, Hair, JH. Chichester: Ellis Horwood.

El-Zemity, S, Hussien, R, Saher, F, Ahmed, Z, 2006: Acaricidal activities of some essential oils and their monoterpenoidal constituents against house dust mite, Dermatophagoides pteronyssinus (Acari: Pyroglyphidae). J. Zhejiang Univ. Sci. B. 7, 12:957-62.

Engelmann, F, 1979: Insect vitellogenin: identification, biosynthesis and role in vitellogenesis. Adv. Insect physiol. 14:49-108.
George, JE, 2000: Present and future technologies for tick control. Ann. N. Y. Acad. Sci. 916: 583-8.

Hasan, M, Sagheer, M, Saleem, S, Hanif, S, Akhter, S, et al, 2012: Evaluation of insecticidal potential of powders of Azadirachta indica, Momordica charentia and Allium sativum against Callosobruchus chinensis (Coleoptera: Bruchidae). Pak. Entomol. 34, 2:71-3.

Isman, MB, 2006: Botanical insecticides, deterrents, and repellents in modern agriculture and an increasingly regulated world. Ann. Rev. Entomol. 51:45-66.

James, AM, Oliver, JH, 1996: Vitellogenin concentrations in the hemolymph and ovaries of Ixodes scapularis ticks during vitellogenesis. Exp. Appl. Acarol. 20:639-47.

Jenni, L, 1971: Synthese and Aufnahme von Proteinen wahrend der Vitellogenese in Ovocyten von Ornithodorus moubata, Murray (Ixodoidea: Argasidae). Acta Trop. 28:105-63 (in German).

Kaiser, MN, 1966: The Subgenus Persicargas (Ixodoidea, Argasidae, Argas). 3. The life cycle of $A$. (P.) arboreus, and a standardized rearing method for argasid ticks. Ann. Entomol. Soc. Am. 59, 3:496-502.

Kostyukovsky, M, Rafaeli, M, Gileadi, C, Demehenko, C, Shaaya, E, 2002: Activation of octopaminergic receptors by essential oil constituents isolated from aromatic plants: Possible mode of action against insect pests. Pest Manag. Sci. 58:1101-6.

Lawson, LD, 1993: Bioactive organosulphur compound of garlic and garlic products role in reducing blood lipids: ACS Symposium Series 534: Human medicinal agents from plants (Eds. Kinghorn, AD, Balandrin, MF,) American Chemical Society, Washington D.C.

Ledezma, E, Apitz-Castro, R, 2006: Ajoene the main active compound of garlic (Allium sativum): a new antifungal agent. Rev. Iberoam. Micol. 23, 2:75-80.

Madhavi, M, 2016: Allium sativum induced protein changes in the ovary of Corcyra cephalonica. Int. J. Adv. Res. 4, 9:961-3

Medina, P, Budia, F, Del Estal, P, Viñuela, E, 2004: Influence of azadirachtin, a botanical insecticide, on Chrysoperla carnea (Stephens) reproduction: toxicity and ultrastructural approach. J. Econ. Entomol. 97, 1:43-50.

Meriga, B, Mopuri, R, MuraliKrishna, T, 2012: Insecticidal, antimicrobial and antioxidant 
activities of bulb extracts of Allium sativum. Asian Pacific J. Trop. Med. 5, 5:391-5

Mohamed, MI, Hafez, SE, 2000: Biological and biochemical effects of the non-volatile plant oil (Jojoba) against Culex pipiens (Diptera: culicidae). J. Egypt. Ger. Soc. Zool. 13, A:65-78.

Mordue, AJ, Nisbet, AJ, 2000: Azadirachtin from the Neem tree Azadirachta indica: its actions against insects. Ann. Soc. Ent. Brasil. 29, 4:615-32.

Olivo, CJ, Heimerdinger, A, Ziech, MF, Agnolin, CA, Meinerz, GR, et al, 2009: Extrato aquoso de fumo em corda no controle do carrapato de bovinos. Cienc Rural. 39, 4: 1131-5.

Pavela, R, 2008: Larvicidal effects of various Euro-Asiatic plants against Culex quinquefasciatus Say larvae (Diptera: Culicidae). Parasitol Res. 102:555-9.

Phulan, MS, Bhatti, WM, Buriro, SN, 1948: Incidence of Argas persicus in poultry. Pakis. Vet. J. 4:174-5.

Priestley, CM, Williamson, EM, Wafford, K A, Sattelle, DB, 2003: Thymol, a constituent of thyme essential oil, is a positive allosteric modulator of human GABA receptors and a homooligomeric GABA receptors from Drosophila melanogaster. Br. J. Pharmacol. 140:1327-63.

Radwan, W, Helmy, N, Shanbaky, N, Bakr, R, Salem, D, et al, 2015: Effect of lufox on haemolymph and ovarian protein in the soft tick, Argas persicus. Egypt. Acad. J. Biol. Sci. 8, 2: 35-48.

Rembold, H, Forster, H, Czoppelt, C, Rao, P J, Sieberk, P, 1984: The Azadirachtins, a group of insect growth regulators from neem trees. In: Schmutterer H, Ascher KRS (eds) Natural pesticides from the neem tree and other tropical plants Proceed. $2^{\text {nd }}$ Inte. Neem Conf., Rauischholzhausen, Eschborn.

Ross, ZM, O'Gara, EA, Hill, DJ, Sleightholme, HV, Maslin, DJ, 2001: Antimicrobial properties of garlic oil against human enteric bacteria: Evaluation of methodologies and comparisons with garlic oil sulfides and garlic powder. Appl. Environ. Microbiol. 67, 1:475-80.

Rousset, A, Bitsch, C, Bitsch, J, 1988: Polypeptide composition and biosynthesis of the yolk proteins in the firebrat Thermobia domestica (Insecta; Thysanura). Arch. Insect Biochem. Physiol. 9:299-312.

Sabuni, ZA, Mbuthia, PG, Maingi, N, Nyaga, PN, Njagi, LW, et al, 2010: Prevalence of ectoparasites infestation in indigenous free-ranging village chickens in different agro-ecological zones in Kenya. Livestock Res. Rur. Develop. 22, 11:1-4.

Schmidt, GH, Rembold, H, Ahmed, AAI, Breuer, M, 1998: Effect of Melia azedarach fruit extract on juvenile hormone titer and protein content in the hemolymph of two species of Noctuid Lepidopteran Larvae [Insecta: Lepidoptera: Noctuidae]. Phytoparasitica 26, 4:283-91.

Seixas, A, Oldiges, D, Vaz, ISJr, Termignoni, C, 2010: Endocrinologia e control da vitelogênese em carrapatos. Acta Sci. Vet. 38, 2:95-111.

Shah, AH, Khan, MN, Iqbal, Z, Sajid, MS, Akhtar, MS, 2006: Some epidemiological aspects and vector role of tick infestation on layers in the Faisalabad District (Pakistan) World's Poul. Sci. J. 62:145-57.

Shanbaky, NM, El-Said, A, Helmy, N, 1990a: Changes in neurosecretory cell activity in female Argas (Argas) hermanni (Acari: Argasidae). J. Med. Entomol. 27:975-81

Shanbaky, NM, Mansour, MM, Main, AJ, Helmy, N, 1990b: Changes in total hemolymph and ovary proteins during oogenesis in Argas (Argas) hermanni (Acari: Argasidae). J. Med. Entomol., 27:985-92.

Shyma, KP, Gupta, JP, Ghosh, S, Patel, KK, Singh, V, 2014: Acaricidal effect of herbal extracts against cattle tick Rhipicephalus (Boophilus) microplus using in vitro studies. Parasitol Res 113, 5:1919-26

Smith, I, 1976: Acrylamide Gel Disc Electrophoresis: Year Book Medical Publishers, Chicago: Sonenshine, DE; Biology of Ticks; Vol. 1, Oxford University Press, Oxford.

Sousa, LAD, Pires, HBJr, Soares, SF, Ferri, P H, Ribas, P, et al, 2011: Potential synergistic effect of Melia azedarach fruit extract and Beauveria bassiana in the control of Rhipicephalus (Boophilus) microplus (Acari: Ixodidae) in cattle infestations. Vet Parasitol. 175, 3/4:320-4.

Sousa, LAD, Soares, SF, Pires, HBJr, Ferri, P H, Borges, LMF, 2008: Avaliação da eficácia de extratos oleosos de frutos verdes e maduros de cinamomo (Melia azedarach) sobre Rhipicephalus (Boophilus) microplus (Acari: Ixodidae). Rev. Bras. Parasitol. Vet. 17, 1:36-40.

Sousa, LAD, Rocha, TL, Morais, SMT, Borges, LMF, 2013: Ovary histology and quantification of hemolymph proteins of Rhipicephalus (Boophilus) microplus treated with Melia azedarach. Rev. Bras. Parasitol. Vet. Jaboticabal. 22, 3:339-45. 
Thorsell, W, Mikiver, A, Tunon, H, 2006: Repelling properties of some plant materials on the tick Ixodes ricinus L. Phytomed. 13:132-4.
Vallae, D, 1993: Vitellogenesis in insects and other groups: A review. Mem. Inst. Oswald, Cruz 88:1-26.

\section{Explanation of Figures}

Fig. 1: Changes in concentration of ovary total protein of adult normal and $1.44 \%$ garlic extract topically treated (on $3^{\text {rd }} \mathrm{DAF}$ ) female $A$. persicus on different days after feeding. Upper line: average protein in mg/ovary of normal samples. Lower line: average protein in mg/ovary of treated samples. Confidence bars shown for $\pm \mathrm{SE}$.

Fig. 2: Electrophoretic protein pattern of whole homogenates from ovary of female A. persicus after different days of feeding.

Fig. 3: Electrophoretic protein pattern of whole homogenates from ovary of treated $A$. persicus females with garlic extract after different days of feeding.
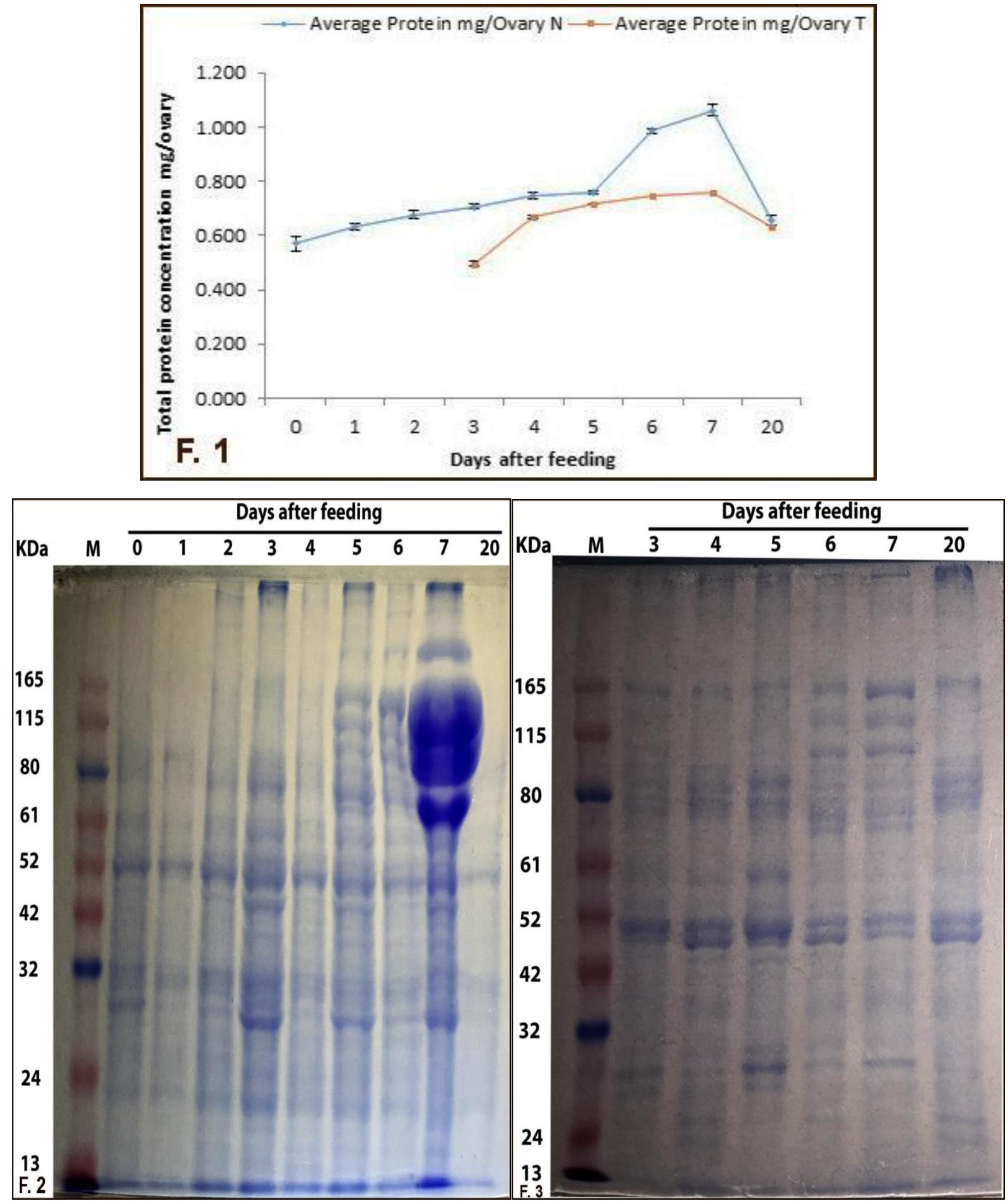